\title{
EMOTIONAL SOURCES OF PERSONALITY
}

In Happiness And Contemporary Society : Conference Proceedings Volume (Lviv, March, 20-21, 2021). Lviv: SPOLOM, 2021. P. 102-104. https://doi.org/10.31108/7.2021.22

ISBN 978-966-919-697-2

\section{ЕМОЦЙНІ ДЖЕРЕЛА ОСОБИСТОСТІ}

// Щастя та сучасне суспільство : збірник матеріалів міжнародної наукової конференції (Львів, 20-21 березня 2021 р.). - Львів : СПОЛОМ, 2021. С. 102-104. https://doi.org/10.31108/7.2021.22

ISBN 978-966-919-697-2 


\author{
FEDORCHUK Olena \\ Researcher, Laboratory of Preschool Psychology \\ G.S. Kostiuk Institute of Psychology \\ of the National Academy of Educational Sciences of Ukraine (Kyiv, Ukraine)
}

\title{
EMOTIONAL SOURCES OF PERSONALITY
}

The report highlights the role of preschool childhood in the process of personality development, analyzes the importance of the family and the main characteristics of subject-subject communication that contribute to the formation of the inner world of the older preschool child. The family is the first and most valuable source of coexistence, first emotional states and feelings. Acceptance (or rejection) of meaningful basic socially significant values by a child occurs on the basis of personal relationships with close adults. The results obtained in the study of the specifics of the value orientations of older preschoolers in the family suggest that children have limited emotional experience of moments of happiness in the family and the inner unwillingness of parents to meaningful communication with the child. Maximum saturation of the process of interaction with the child with positive emotions, values and empathic actions of adults contributes to the harmony of feelings, thinking and imagination of the child. Only in an atmosphere of happiness does a child learn to think about "happiness" and feel it.

KEY WORDS: preschooler, subject-subject communication, emotions, happiness

\author{
ФЕДОРЧУК Олена \\ науковий співробітник лабораторії психологї дошкільника \\ Інституту психології ім. Г.С.Костюка НАПН України (Київ, Україна)
}

\section{ЕМОЦІЙНІ ДЖЕРЕЛА ОСОБИСТОСТІ}

Секрет дошкільного дитинства в тому, що свої уявлення про щастя, любов, добро і зло, честь і гідність, свої критерії краси, як основу людяності виникають $\mathrm{i}$ закріплюються у дитини через призму відповідних уявлень батьків. Саме в процесі тісних взаємин життєвого спілкування дитина створює свій образ-ідеал, 3 яким і співвідносить свої відчуття, роздуми, дії і перші вчинки. Дитяче сприймання світу через люблячих турботливих батьків проходить через розум і серце дитини і $\epsilon$ своєрідним, безпосереднім, щирим і тонким. Такого іншого періоду для виховання батьківською любов'ю самодостатньої особистості 3 міцним фундаментом іiі емоційної культури не має в жоден період життя.

Структура людських цінностей формується не на основі вроджених $\mathrm{i}$ підсвідомих внутрішніх тенденцій, а на грунті свідомого, осмисленого відображення зовнішньої дійсності. У кожної дитини свій шлях сходження до сприйняття та привласнення цінностей, який позначається чинниками, що створюють індивідуальність. Наслідування близькому дорослому та доступність самої життєвої ситуації для осмислення дитиною тут виступає додатковими чинниками. За Л.С.Виготським лише власна цілеспрямована активна діяльність та активна взаємодія дитини 3 духовно-культурним середовищем, іншими людьми здатна запустити процес виникнення психологічних якісних новоутворень. 
Сім'я є найпершим носієм та зберігачем загальнолюдських цінностей для дитини, найсильнішим, a відтак i найціннішим джерелом впливу, що забезпечується безмежною батьківською любов'ю і відповідальністю за щасливе майбутнє дитини. Це найближча відкрита дитячій душі школа життя. Засвоєний в процесі щирого і переконливого спілкування в колі сім'ї досвід співжиття та співіснування включає перші емоційні стани та відчуття. Старший дошкільник стає особливо чутливий до характеру особистісних взаємин 3 близькими дорослими. А саме в процесі цих взаємин і відбувається прийняття (або відторгнення) осмислених перших базових соціально значимих цінностей дитиною. Дитина завжди тонко відчуває чи є дорослий суб'єктом цінності, яку їй намагаються прищепити, чи співпадає розуміння суті тої чи іншої цінності зі сприйняттям дорослого.

Здатність дитини заражатись емоціями оточуючих $\mathrm{i}$ схильність до наслідування близьких служить прекрасною основою для вироблення умінь виражати свої почуття, і формування потреби в емоційній співзвучності 3 оточуючими, готовності до проявів чуйності. Постійно пам'ятаючи, що своєю поведінкою дорослий створює для своєї дитини модель емоційних станів та відчуттів, приклади емоційного ставлення до близьких дорослих, до родини, а згодом і до інших людей, бажано комунікативні взаємини з дитиною щедро насичувати емоційно-безпосередніми контактами. Саме в процесі суб'єктсуб'єктної комунікації зароджуються емоційно-смислові відчуття, ставлення малюка, уявлення про себе і навколишній світ, про способи взаємодії з ним. Дуже важливо, щоб така комунікація була для дитини джерелом позитивних емоцій, ресурсних станів та відчуттів. Дитина має бути свідком лише тих способів поведінки дорослого, які він очікує від неї.

Як показали результати дослідження серед 17 цінностей взятих для вивчення поля цінностей родин, що виховують дітей дошкільного віку, цінність «щастя» для більшості

не $є$ темою для розмов та дискусій та посідає передостаннє місце $(40 \%)$ за рівнем приділеної уваги в родині: найбільшої уваги у комунікації з дітьми дорослі приділяють цінностям дружба (100\%) та сміливість (100\%). На другому місці стоять цінності сім'я (80\%), здоров'я (80\%) та гроші (80\%). Щоправда, на думку дорослих, цінність «щастя» $€$ однією 3 найбільш сформованих у дітей поряд 3 цінностями «сім'я», «краса природи», «допитливість». Мова йде про перше цілісне усвідомлення дитиною самої себе в поєднанні з привласненими цінностями ( я щасливий, я - добрий, я - сміливий, я - хороший друг і т.п.)., що є достатньо умовним, поверховим та неосмисленим на рівні глибоких почуттів. Дитячі емоційні тлумачення тут $є$ більш виразні та окреслені ніж усвідомлення самих смислів. Більшість дітей (85\%) трактують поняття «щастя» як моменти в житті, коли відчуваєш радість: «коли людина усміхається, радіє», «коли дитина радіє», «коли весело»; наявність братів чи сестер - $2 \%$; «бути сильним» $-1 \%$; отримання матеріальних благ: «коли щось купляють» - 5\%; «поїздка на море, річку» - 2\%; «щастя виглядає як добро» - 1\%. Аналіз асоціативного ряду поняття «щастя» батьків дав наступні результати: здоров'язбережувальний аспект: «здоров'я», «здоров'я близьких», «здорова родина» - 24\%; емоційний аспект: «любов», «кохання», «радість», «теплі стосунки» - 20\%; соціальний аспект: «сім'я», «родина», «батьки», «дитинство» - 20\%; соціально-психологічний аспект: 
«гармонія», «єднання», «свобода», «благополуччя» - 10\%; матеріально-споживчий аспект: «торт», «гроші», «квіти», «квитки»- $14 \%$.

Отримані відповіді говорять про обмеженість у дітей емоційного досвіду переживань моментів щастя в у сімейному колі. Дехто 3 батьків вважає, що діти ще не готові до розмов про щастя, любов, інші ж, не відчуваючи в собі внутрішньої готовності, свідомо уникають таких розмов. Цільові спостереження і бесіди 3 батьками 3 проблеми спілкування їх з дітьми показали, що лише $15 \%$ батьків виявляють зацікавленість у змістовному спілкуванні 3 дитиною. Завданням дорослих є підтримувати та оберігати зародження інтересу дитини до свого внутрішнього світу, допомога в усвідомленні змістової складової. Дитина має бути активним суб'єктом гуманних переживань в реальних умовах. Максимально насичуючи процес взаємодії 3 дитиною позитивними емоціями, ціннісними смислами та емпатійними діями дорослі тим самим забезпечують гармонію почуттів, мислення та уяви дитини. Важливо створювати ситуації, де дитина вчиться думати про «щастя» і вчиться дорожити тим, що викликає у неї позитивні емоції.

\section{ЛІТЕРАТУРА}

1. Федорчук О.І. Основи сімейної соціалізації дошкільника. Актуальні проблеми психології: зб. наук. пр. Інституту психології імені Г.С. Костюка НАПН України. Харків: КЦ ФОП Іванової М.A., 2020. Том. IV: Психологія розвитку дошкільника. Вип. 16. С. 222-235.

2. Федорчук О.І. Внутрісімейне спілкування як чинник привласнення дитиною цінностей співжиття. Актуальні проблеми психології: зб. наук. пр. Інституту психології імені Г.С. Костюка НАПН України. Харків: КЦ ФОП Іванової М.А., 2019. Том. IV: Психологія розвитку дошкільника. Вип. 15. С. 207-220.

3. Прийняття дитиною цінностей : посіб. / Т.О. Піроженко, I.I. Карабаєва, С.О. Ладивір, Л.І. Соловйова [та ін.] : за ред. Т.О. Піроженко. Київ Видавничий Дім „Слово”, 2018. 240 с. 